\title{
TRUSTS: CONDUIT THEORY ADOPTED TO ALLOCATE REGULATED INVESTMENT COMPANY'S CAPITAL GAINS DIVIDEND TO PRINCIPAL
}

R EGULATED investment company distributions from capital gains, in whatever form, are properly allocated to principal, absent the contrary intention of the settlor, according to the recent case of Tait $v$. $P e c k,{ }^{1}$ decided by the Supreme Judicial Court of Massachusetts.

Petitioner, a widow and the life beneficiary of an inter vivos trust established by her husband, sought a declaratory judgment that the capital gains dividends from a regulated investment company, payable in cash or stock at the trustee's option, were income. Both the individual remaindermen and the trustee, respondents, asserted that the distribution was a return of capital and should be added to principal. The parties stipulated that the trust instrument did not show the settlor's intention with respect to capital gains distributions. Unencumbered by Massachusetts precedent, the court surveyed the confiicting arguments and adopted the view that a regulated investment company is functionally a conduit for passing any realized capital gains to the trust fund, and that these gains should retain their character as principal. ${ }^{2}$

Though controversy over the proper allocation of capital gains dividends declared by regulated investment companies has been both fierce and long, ${ }^{3}$ all courts which previously have decided the issue have allocated this type dividend to income rather than to principal. 4 Where the trustee has the option to take either cash or

194 N.E.2d 707 (Mass. 1963).

2 Id. at 713-14.

${ }^{3}$ For a brief discussion and rejoinder of the partisan view points, see Shattuck, Capital Gain Distributions-Principal or Income?, 88 TRusts \& EsTATES 160 (1949); Young, A Dissent on Capital Gain Distributions, 88 Trusts \& Estates 280 (1949); Shattuck, Further Comment on Capital Gain Distributions, 88 TrusTs \& EsTATES 429 (1949); Young, More About Capital Gains, 88 Trusts \& Estates 467 (1949).

See generally BogerT, TRUSTS AND TRUSTEes $\$ 858$ (2d ed. 1962) [hereinafter cited as BOGERT]; 3 SCOTT, TRUSTS $\$ 236.14$, at 1844-45 (2d ed. 1956) [hereinafter cited as ScorT]; Cohan \& Dean, Legal, Tax and Accounting Aspects of Fiduciary Apportionment of Stock Proceeds: The Non-Statutory Pennsylvania Rules, 106 U. PA. L. REv. 157, 181 83 (1957); Dunham, Scott \& Wolf, Uniform Revised Principal and Income Act-Discussion of Newly Promulgated Statute, 101 Trusts \& Estates 894, 897 (1962).

4 Rosenburg v. Lombardi, 222 Md. 346, 160. A.2d 601 (1960); Briel v. Moody, 77 N.J. Super. 306, 186 A.2d 314 (Ch. 1962); In the Matter of Bruce's Trust, 192 Misc. 523, 81 N.Y.S.2d 25 (Sup. Ct. 1948); In the Matter of Estate of Snitzer, 33 Misc. 2d 692, 226 N.Y.S.2d 279 (Surr. Ct. 1962); In the Matter of Estate of Appleby, 15 Misc. 2d 200, 
stock, the dividends have been treated as cash distributions, regardless of the trustee's choice. ${ }^{5}$ These decisions conform to the majority rule adopted by the Uniform Principal and Income Act ${ }^{6}$ which looks solely to the form of the distribution. ${ }^{7}$ The present decision represents an exception to the general rule by holding that the source, regardless of the form, should control the allocation of a regulated investment company's dividend between income and principal. This casenote analyzes the validity of the various arguments

175 N.Y.S.2d 176 (Surr. Ct. 1958), 27 FordhaM L. Rev. 645 (1959); In the Matter of Estate of Byrne, 192 Misc. 451, 81 N.Y.S.2d 23 (Surr. Ct. I948); Lovett Estate (No. 2), 78 Pa. D. \& C. 21 (Orphans' Ct. 1951). See Coates v. Coates, 304 S.W.2d 874, 876 (Mo. 1957); In re Whitehead's Will Trusts, [1959] I Ch. 579, 590-92.

- E.g., Coates v. Coates, supra note 4; In the Matter of Estate of Appleby, supra note 4; In the Matter of Will of Hurd, 203 Misc. 966, I20 N.Y.S.2d 103 (Surr. Ct. 1953); Kellogg v. Kellogg, 166 Misc. 791, 4 N.Y.S.2d 219 (Sup. Ct.), aff'd mem. sub nom. Kellogg v. Neale, 254 App. Div. 812, 5 N.Y.S.2d 506 (1938).

- Section 5(1) (1931): "All dividends on shares of a corporation forming a part of the principal which are payable in the shares of the corporation shall be deemed principal. Subject to the provisions of this section, all dividends payable otherwise than in the shares of the corporation itself, including ordinary and extraordinary dividends and dividends payable in shares or other securities or obligations of corporations other than the declaring corporation, shall be deemed income. Where the trustee shall have the option of receiving a dividend either in cash or in shares of the declaring corporation, it shall be considered as a cash dividend and deemed income, irrespective of the choice made by the trustee."

As of 1963, twenty-nine states, which did not include Massachusetts, had adopted the Uniform Principal and Income Act, some only after substantial revision. See BOGERT $\$ 816 ; 3$ SCOTT $\$ 241$ A.

7 The Uniform Principal and Income Act adopted the so-called Massachusetts rule, first laid down in Minot v. Paine, 99 Mass. 101, 108 (1868), for allocating corporate distributions: "A simple rule is, to regard cash dividends, however large, as income, and stock dividends, however made, as capital." Respondents argue that Massachusetts does not in fact blindly follow the rule which bears its name and that where the mode of payment does not accurately reflect the nature of the corporate distribution, the source and not the form determines its allocation. Brief for Respondents, pp. 9-15.

The minority or so-called Pennsylvania rule endeavors to allocate corporate distributions according to source, requiring some apportionment between principal and income. Earp's Appeal, $28 \mathrm{~Pa}$. 368 (1857). This rule applies only to extraordinary dividends of cash or stock: the dividends are treated as income to the extent that they constitute a distribution of earnings accruing since the creation of the trust, but to the extent that they do not they are alloctaed to principal. Supporters of this rule urge that it reaches a more equitable result than does the Massachusetts rule. However, in the prefatory note to the Uniform Principal and Income Act, the Commissioners, in rejecting the Pennsylvania rule, declared: "Experience has shown that, however praiseworthy the intent, the [Pennsylvania] rule is unworkable, since neither trustee nor court has the means to value the corporate assets in such way as to secure the fair adjustment aimed at." HANDBOoK of THE NATIONAL CoNference of Commissioners on Uniform State Laws and Proceedings 327 (1931).

See generally BOGERT $\$ \S 841-52$; LORING, A TrusTEE's HANDBOOK $\$ \S$ 83-106 (Farr Rev. 1962); 3 Scotr $\$ 236$.15; Flickinger, A Trustee's Nightmare: Allocation of Stock Dividends Between Income and Principal, 43 B.U.L. REv. 199 (1963).

8 The Revised Uniform Principal and Income Act $\S 6(c)$ (1962) provides, however, 
advanced for deciding the proper allocation of capital gains dividends declared by a regulated investment company.

Where the actual intention of the settlor is discernible in the trust instrument it must be carried out, ${ }^{9}$ provided it does not contravene public policy. In the absence of expressed intention, the settlor might be presumed to favor the life beneficiary, who is more apt to be the natural object of the settlor's bounty, rather than the possibly remote remainderman; ${ }^{10}$ thus, the capital gains dividend should go to income. This position, based on presumed intention, seems tenuous, however, since it directly conflicts with the trustee's duty to act impartially in any dealings affecting the beneficiaries. ${ }^{11}$

Because the return of ordinary income from a regulated investment company is sometimes comparatively low, ${ }^{12}$ it is urged that, unless the income beneficiary is given the capital gains dividends, an investment company is an unfair and improper investment for a trust. However, it does not necessarily follow that the low income return should be determinative of the proper allocation of dividends between principal and income. In keeping with his duty to deal impartially with all beneficiaries, the trustee must consider the relative amounts of capital gains and ordinary income dividends, as well as their proper allocation, when he selects any particular trust investment; generally he should choose an investment company

that "Distributions made from ordinary income by a regulated investment company ... are income. All other distributions made by the company ... including distributions from capital gains, depreciation, or depletion, whether in the form of cash or an option to take new stock or cash or an option to purchase additinal shares, are principal." See Barclay, The Revised Uniform Principal and Income Act, 101 Trusts \& ESTATIS 833 (1962).

For criticism of this section, see Bogert, The Revised Uniform Principal and Income Act, 38 NOTRE DAME LAw. 50, 53-55 (1962).

${ }^{\circ}$ E.g., In re Trusts under Will of Whitacre, 208 Minn. 286, 289, 293 N.W. 784, 785 (1940); In the Matter of Estate of Fisher, 115 N.J. Eq. 329, 332, 171 Atl. 169, 171 (Ct. Err. \& App. 1934); In the Matter of Heinrich, 195 Misc. 803, 808, 90 N.Y.S.2d 875, 880 (Surr. Ct. 1949); Restatement (SECond), Trusts $\$ 236$, comment $b$ (1959); 3 Scotr § 236.15; Comment, 31 Rocky MT. L. REv. 224, 226-27 (1959).

I0 BOGERT § 858, at 557; Comment, supra note 9, at 228; 3 SCOTT $\$ 236.3$, at 1819-20 (casts some doubts on this presumption of the settlor's intent).

${ }^{11}$ See, e.g., Security Trust Co. v. Mahoney, 307 Ky. 661, 668-69, 212 S.W.2d 115, 119 (1948); Restatement (SECOND), Trusts $\$ \S 183,232$ (1959); 2 Scotr $\$ 183 ; 3$ id. $\S$ 232.

${ }^{12}$ BOGERT $\S 858$, at 555,559 . For a compilation of data showing the capital gains and income returns of a selected list of investment companies, see Long, The Index of Mutual Investment Companies, 88 Trusts \& Estates 431, 432-33 (1949); Long, Index of Mutual Funds, 96 Trusts \& Estates 48 (1957). See also Wiesenderger, INVESTMENT CoMPanies 1963 pt. I, at 39-40 (23d annual ed. 1963) [hereinafter cited as WIESENBERGER]. 
which balances growth investments with income-producing investments. ${ }^{13}$ If the trustee chooses wisely, it is hard to see how the income beneficiary is harmed.

Conversely, it may be persuasively contended on behalf of the remainderman that it is unfair to allocate the capital gains dividends to income. The burden of paying the initial investment charges and expenses, which are substantial in the case of most investment companies, usually falls upon principal. ${ }^{14}$ Hence, by returning capital gains to principal, these costs can be recovered over a period of time. If the capital gains dividends are allocated to income, this gives the income beneficiary all the benefits resulting from a fluctuating market, while the remainderman bears all the losses. ${ }^{15}$ Furthermore, if capital gains are not allocated to principal, the remainderman will be denied the normal appreciation in trust corpus which usually occurs in an inflationary economy. ${ }^{16}$ On the other hand, reinvesting the capital gains in principal protects the remainderman without being greatly detrimental to the life beneficiary: the remainderman is not prejudiced by bearing all the losses from an active market, and the income beneficiary gets new and additional income produced by the increased capital.

Because the rule adopted in Tait $v$. Peck requires the trnstee to allocate dividends according to their underlying source, it has

${ }^{13}$ See authorities cited note 11 supra. See also Wresenberger pt. 1, at 62-74.

14 E.g., In the Matter of Estate of Campbell, 382 P.2d 920, 967 (Hawaii 1963); In the Matter of Estate of Schepp, 9 N.Y.S.2d 112 (Surr. Ct. 1938); Patterson v. Old Dominion Trust Co., 156 Va. 763, 159 S.E. 168 (1931); BOGERT \$ 803, at 142-43; Restatement (SECOND), TRUSTS $\S 233$, comment $f$ (1959); 3 ScoTr $\$ 233.3$, at 1756 . Both the Uniform Principal and Income Act $\S 12(2)$ (1931) and the Revised Uniform Principal and Income Act $\S 13$ (c) (2) (a) (1962) charge the costs of investing and reinvesting to principal.

Contra, Hite's Devisees v. Hite's Ex'r, 93 Ky. 257, 20 S.W. 778 (1892) (investment expenses apportioned between income and principal); Jordan v. Jordan, 192 Mass. 337, 78 N.E. 459 (1906) (income pays investment costs); Sedgwick v. Sedgwick, 74 Ohio App. 435, 59 N.E.2d 611 (1944) (income pays investment costs); Rhode Island Hosp. Trust Co. v. Waterman, 23 R.I. 342, 50 Atl. 389 (1901) (apportioned investment costs).

16 Tait v. Peck, 194 N.E.2d 707, 712 (Mass. 1963); Brief of the Investment Company Institute as Amicus Curiae, p. 9; Brief for Respondents, pp. 18-20. See Putney, Capital Gain Dividends-Should They Be Allocated to Income or Principal, 95 TRUsts \& EsTATES 22 (1956); Shattuck, Capital Gain Distributions-Principal or Income?, 88 Trusts \& Estates 160 (1949); Shattuck, Further Comment on Capital Gain Distributions, 88 TRusts \& EsTates 429 (1949).

But see Rosenburg v. Lombardi, 222 Md. 346, 353, 160 A.2d 601, 605 (1960) (recognizing the argument, but finding it inapplicable in this case).

10 Tait v. Peck, supra note 15, at 708, 712; Brief of the Investment Company Institute as Amicus Curiae, p. 7. 
been urged that difficult accounting problems may arise. ${ }^{17}$ In most contexts this argument is quite persuasive. The minority rule, requiring apportionment of the corporate distribution of earnings according to source, while theoretically equitable, often involves such complex accounting as to be impractical. ${ }^{18}$ However, apportioning the dividends of regulated investment companies does not necessitate intricate inquiries into the company's accounts to find the source, since the company itself provides a break down of its distribution according to source, as required by law..$^{10}$

In jurisdictions which have a policy against allowing the accumulation of income, ${ }^{20}$ declaring the capital gains dividend to be principal, as done in this case, will permit more flexible drafting of of trust agreements. ${ }^{21}$ But where capital gains dividends are regarded as "income," trust agreements which authorize the trustee to allocate these dividends to principal might be held invalid as an attempt to accumulate income..$^{22}$ On the other hand, holding capital gains to be principal escapes this problem, since there is no corre-

\footnotetext{
${ }^{17} 194$ N.E.2d at 713. Professor Scott says that simplicity is perhaps the strongest argument in favor of the so-called Massachusetts rule, which allocates corporate distributions according to form. 3 Scort $\$ 236.3$, at 1818 . Sce note 7 supra.

${ }^{18}$ E.g., In re Arens, 72 N.J. Super. 310, 178 A.2d 119 (P. Ct. 1962); Flickinger, supra note 7 , at 211-29. See other authorities cited note 7 supra. Sce gencrally BoGERT \$§ 847-48; Cohan \& Dean, supra note 3, for a discussion of the so-called Pennsylvania or minority rule.

${ }^{10}$ Investment Company Act $\S 80 \mathrm{a}-19,54$ Stat. 821 (1940), 15 U.S.C. $\S 80 \mathrm{a}-19$ (1958): "It shall be unlawful for any registered investment company to pay any dividend, or to make any distribution in the nature of a dividend payment, wholly or partly from any source other than-(1) such company's accumulated undistributed net income, determined in accordance with good accounting practice and not including profits or losses realized upon the sale of securities or other properties; or (2) such company's net income so determined for the current or preceding fiscal ycar; unless such payment is accompanied by a written statement which adequately discloses the source or sources of such payment." (Emphasis added.)

The Revised Uniform Principal and Income Act $\$ 6(e)$ provides that "the trustce may rely upon any statement of the distributing corporation as to any fact relevant under any provision of this Act concerning the source or character of dividends or distributions of corporate assets."

${ }^{20}$ For a comprehensive discussion of the rules on accumulations, and a presentation of the applicable provisions of various state statutes, see $1 \mathrm{~A}$ BocERT $\$ \S 215-17$. Sce also Note, 44 CORNELL L.Q. 284 (1959).

${ }^{21}$ See generally Anderson, Should Capital Gain Distributions Be Principal or Income?, 90 Trusts \& EsTATEs 530 (1951); Rogers, Capital Gain Distributions-Clauses to Eliminate Question of Allocating Investment Company Dividends, 90 Trusts \& EsTaTes 300 (1951); Rogers, Capital Gain Dividends-A Suggestion for Draftsmcn, 20 FordhaM L. REv. 79 (1951).

${ }^{22}$ E.g., Warden Trust, $382 \mathrm{~Pa} .311,115$ A.2d 159 (1955); Maris's Estate, $301 \mathrm{~Pa}$. 20, 151 Atl. 577 (1930). But see Equitable Trust Co. v. Prentice, 250 N.Y. 1, 164 N.E. 723 (1928); In the Matter of Feinrich, 195 Misc. 803, 90 N.Y.S.2d 875 (Surr. C. 1949).
} 
sponding prohibition against a settlor's providing in his trust deed for the invasion of principal for the support of the income beneficiary. ${ }^{23}$

The fact that Congress has adopted the conduit theory for purposes of taxing the income of regulated investment companies has been seized upon as an indication that these dividends should be allocated to principal by the trustee. ${ }^{24}$ It is argued that if such capital gains dividends are paid to the income beneficiary, Congress might decide to tax them as ordinary income. ${ }^{25}$ This argument seems spurious, however, since the source of a receipt, and not the recipient, determines the designation for tax purposes. ${ }^{26}$ Yet, in so far as the tax policy recognizes and echos the underlying economic realities of investment companies, the tax aspect is a persuasive indication that capital gains dividends are, in fact, a return of principal.

Perhaps the basic controversy centers around the disagreement as to the purposes and functions of regnlated investment companies. ${ }^{27}$ Investment companies are a special type of corporation which are closely regnlated by the Investment Company Act of 1940.28 Their primary business purpose consists of investing, reinvesting, or trading in securities. ${ }^{29}$ They provide a way for relatively small investors to pool and invest their funds to secure expert investment management and broad diversification of risk. ${ }^{30}$ Investment companies differ from other types of trading corporations in that they do not engage in such business activities as manufacturing, mining, retailing, or transportation. Through their activity of investing, reinvesting, and trading their portfolio securities, investment com-

\footnotetext{
${ }^{23}$ See 2 Scott $\$ 128.7$.

${ }^{24}$ INT. REv. CoDE of 1954, § 852. An investment company which distributes at least $90 \%$ of its ordinary income to its shareholders is not taxed on this income. $\S$ 852 (a) (1). Instead the stockholder pays the regular federal income tax on this income. However, dividends designated by the investment company as capital gains are taxed at the long term capital gains rate. $\$ 852$ (b) (3) (B). Even if the capital gains are retained by the company, they are still taxed at the capital gains rate, and the shareholder may claim a credit on his tax return for the tax paid by the mutual fund. $\$ 852$ (b) (3) (D).

${ }^{20}$ See BOcERT $\$ 858$, at 556. Professor Bogert rejects this argument.

${ }^{20}$ E.g., Merchants' Loan \& Trust Co. v. Smietanka, 255 U.S. 509, 521 (1921); In the Matter of Estate of Byrne, 192 Misc. 45I, 81 N.Y.S.2d 23 (Surr. Ct. 1948); Lovett Estate (No. 2), 78 Pa. D. \& C. 21 (Orphans' Ct. 1951). See BoGERT $\S 858$, at 557.

${ }^{37}$ See, e.g., the discussions of Shattuck and Young, cited supra note 3.

${ }^{28} 54$ Stat. 789 (1940), I5 U.S.C. $\$ \$ 80 \mathrm{a}-1$ to $80 \mathrm{a}-52$ (1958). See Note, The Investment Company Act of 1940, 41 Colum. L. REv. 269 (1941).

${ }^{20}$ Investment Company Act, supra note 28 , at $\$ 80 \mathrm{a}-3$ (a) (1). See generally WIESENBERGER pt. I.

${ }^{30}$ See Note, supra note 28 . See also Wiesenberger pt. I, at 18-21.
} 
panies realize profits which they are required to break down into capital gains and ordinary income, and all of which they generally pay out to their shareholders as dividends. ${ }^{31}$

On behalf of the income beneficiaries, it is argued that a regulated investment company should be treated just like any other ordinary, corporate entity and that all the profits, including the part from capital gains, should be allocated to income. ${ }^{32}$ The portifolio securities are considered tantamount to the "working capital" or inventory of the company, as distinguished from permanent capital assets. ${ }^{33}$ Furthermore, analogies are drawn to the situations where a corporation's business is buying and selling land from which it realizes its profits, ${ }^{34}$ or where one corporation divests itself of stock which it holds in another and distributes the proceeds in cash or in its own stock at the option of the recipient: ${ }^{35}$ in both of these cases the dividends go to income.

In opposition to this pure entity treatment, it is contended that it is more realistic to regard a regulated investment company in the nature of a conduit for passing the profits on to the proper beneficiary as if the trustee had owned the underlying stocks directly. ${ }^{30}$ The reasons for which an investor chooses to invest in an investment company have no connection with the investment company's corporate form. ${ }^{37}$ There may be no other way open for a trustee to get ex-

${ }^{31}$ WIESENBERGer pt. I, at 39-46; Choka, An Introduction to Investment Companies, 3 Prac. LAW 48 (Feb. 1957).

${ }^{32}$ See cases cited note 4 supra.

${ }^{33}$ E.g., Young, $A$ Dissent on Capital Gain Distributions, 88 Trusts \& Estates 280 (1949).

${ }^{34}$ E.g., In the Matter of Estate of Gartenlaub, 185 Cal. 375, 197 Pac. 90 (1921); Krug v. Mercantile Trust \& Deposit Co., 133 Md. 110, 104 Atl. 414 (1918); Recd v. Head, 88 Mass. (6 Allen) 174 (1863); Matter of Jackson, 258 N.Y. 281, 179 N.E. 496 (1932); 3 Scotr $\S 236.14$, at 1843. But see Rhode Island Hosp. Trust Co. v. Bradley, 41 R.I. 174, 103 Atl. 486 (1918).

${ }^{35}$ See, e.g., Old Colony Trust Co. v. Jameson, 256 Mass. 179, 152 N.E. 52 (1926) (dividend of subsidiary's stock goes to income); Coates v. Coates, 304 S.W.2d 874 (Mo. 1957) (optional cash or stock dividend goes to income); City Bank Farmers Trust Co. v. Ernst, 263 N.Y. 342, 189 N.E. 241 (1934) (dividend of subsidiary's stock goes to income); In the Matter of Estate of Appleby, 15 Misc. 2d 200, 175 N.Y.S.2d i76 (Surr. Ct. 1958), 27 Fordham L. Rev. 645 (1958-1959) (optional cash or stock dividend goes to income); UnIform Principal and Income Act $\S 5(1)$, note 6 supra; Flickinger, supra note 7, at 200-01.

${ }^{30}$ Tait v. Peck, 194 N.E.2d 707, 712-14 (Mass. 1963); Brief of the Investment Company Institute as Amicus Curiae, pp. 11-15; Brief for Respondents, pp. 5.9. Sce Putney, supra note 15 , at 24.

${ }^{37}$ See Ewart, Principal and Income Problems of Trustees with Mutual Fund Dividends, 95 Trusts \& Estates 1025, 1028 (1956). 
perienced management and risk diversification in his investments. ${ }^{38}$ Instead of the trustee's owning directly a small number of shares in a large number of investments (often an impossibility in small trusts, and inconvenient in large ones), the trustee owns shares of an investment company, which in turn invests the money paid by the trustee for its stock in the stock of other companies. ${ }^{39}$

To buttress this argument for treating investment companies as a conduit, an analogy may be drawn to common trust funds set up by banks as trustees. ${ }^{40}$ In common trust funds the assets of several trusts are commingled and invested by the trustee-bank in a group of securities, each estate managed by the trustee-bank having a fractional interest in the whole group. The same advantages of experienced management, risk diversification, and convenience realized through the investment company are found in common trust funds. ${ }^{41}$ Notably, capital gains realized by buying and selling the portfolio securities of a common trust fund are returned to principal. ${ }^{42}$ Also, capital gains received by a trustee from the sale of securities held by himself as trustee, and not a part of any common trust fund or investment company, are allocated to principal. ${ }^{43}$

${ }^{s 8}$ Common trust funds are restricted to funds maintained by a bank as trustee, and are controlled by rules of the Board of Governors of the Federal Reserve System. No funds of any outsider can be invested in the common trust fund. The maximum amount from any one trust which can be invested in a common trust fund is $\$ 100,000$. See 12 C.F.R. $\$ 206.17$ (1959); 3 Scotr $\$ 227.9$, at 1684-85; Capron, The Federal Reserve Board Regulations of Common Trust Funds, 5 LAw \& ConTEMP. Prob. 439 (1938).

${ }^{80}$ Tait v. Peck, 194 N.E.2d 707, 712 n.9 (Mass. 1963). See Wirsenberger pt. V, for a listing of the various stocks comprising the portfolios of the individual investment companies.

${ }^{10}$ Tait v. Peck, supra note 39, at 712-13. However, the analogy is not perfect, since there are no fees, in addition to the trustee's commission, charged for the management services of a common trust fund as contrasted to the substantial initial costs of investing in investment companies. 12 C.F.R. $\$ 206.17$ (c) (8) (1959). The court suggested that a trustee who invests in regulated investment companies should perhaps receive a lower trustee's commission because he is not burdened with the investment management. However, "[t] possible meager return does not change the substance of the investment as a reasonable attempt at risk diversification similar to that of the common trust fund." Tait v. Peck, supra at 713. See Bocerr $\S 679$, at 311-13; 3 Scorr § 227.9A.

By the better rule, these investment costs should properly be borne by principal. See authorities cited note 14 supra and accompanying text.

«1 3 Scorr $\$ 227.9$, at 1683.

¿'Tait v. Peck, 194 N.E.2d 707, 713 (Mass. 1963); Ward, Problems in the Administration of Common Trust Funds, 5 LAw \& ConTEMP. ProB. 453, 460-61 (1938).

${ }^{13}$ E.g., In re Trust under Will of Koffend, 218 Minn. 206, 223, 15 N.W.2d 590, 599 (1940); Welch v. Welch, 235 Wis. 282, 341-43, 290 N.W. 758, 785 (1940). See RestateMENT (SECOND), TRUSTs $§ 236$ (f), comment $x$, at 580 (1959): “ $A$ dividend which represents only the natural growth or increase in value of the property representing the 
There is no essential economic difference between capital gains realized by the trustee on sales of trust securities which he holds directly, or as part of a common trust fund, and capital gains resulting from the sale of securities from the investment company portfolio. The only real difference is the intervention of the corporate entity. ${ }^{44}$ While recognizing that an investment company is a legal, corporate entity for some purposes, it is being overly conceptualistic to conclude that this must dictate the proper allocation of a dividend between principal and income for trust purposes. On balance, it seems that the conduit theory, by allocating capital gains dividends to principal and ordinary dividends to income, more nearly accords with the economic facts, and with the basic purposes and functions of a regnlated investment company.

From the trustee's point of view, probably the most important consideration is to establish a definite, workable rule of law. The rule announced in Tait $v$. Peck satisfies this need, is fair and simple, has recently been enacted by several state legislatures, ${ }^{45}$ and follows the position adopted by the Revised Uniform Principal and Income Act in 1962.46 However, the rule in Tait $v$. Peck $^{47}$ probably should be limited to the regulated investment company situation, where the company itself denominates the source of the dividend. Otherwise the trustee may once again find himself entangled in the complicated accounting jungle of tracing the source of the receipts and apportioning them between principal and income.

original capital of the corporation, or of the permanent property or good will, is principal." See also 3 Scort \$ 236.14, at 1841-42.

4 Tait v. Peck, 194 N.E.2d 707, 713 (Mass. 1963); Brief of the Investment Company Institute as Amicus Curiae, p. II.

${ }^{45}$ See, e.g., Fla. Stat. AnN. \$ 690.06 (Supp. 1962); N.Y. Pers. Pror. LAW $\$ 17$ (a) (Supp. 1963).

is See note 8 supra.

47 N.E.2d at 713-14. 